\title{
The Relation of Elite, Sub-Elite, and Village Community in Maintaining the Masra Family Dynasty in Gapurana Village, Sumenep Regency: Study on the H. Andiwarto Regime in 2013-2019
}

\author{
Ruth Agnesia Sembiring 1,*, (D), and Mishbahul Khoiri 2, (D) \\ ${ }^{1}$ Department of Government Science, Faculty of Administrative Science, \\ Universitas Brawijaya, 65145, Malang, East Java Province, Indonesia \\ 2 Department of Public Administration, Faculty of Administrative Science, \\ Universitas Brawijaya, 65145, Malang, East Java Province, Indonesia \\ * Corresponding Author: nesi.biring@gmail.com
}

\section{ARTICLE INFO}

\section{Publication Info: \\ Research Article}

How to cite:

Sembiring, R. A., E Khoiri, M. (2021). The Relation of Elite, SubElite, and Village Community in Maintaining the Masra Family Dynasty in Gapurana Village, Sumenep Regency: Study on the H. Andiwarto Regime in 20132019. Society, 9(2), 420-428.

DOI: 10.33019/society.v9i2.271

Copyright (c) 2021. Owned by Author(s), published by Society

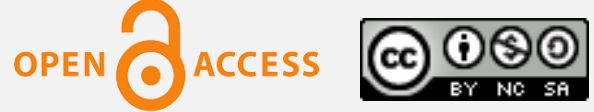

This is an open-access article.

License: Attribution-

NonCommercial-ShareAlike (CC BY-NC-SA)

Received: November 30, 2020; Accepted: June 29, 2021; Published: December 31, 2021;

\section{ABSTRACT}

This research focuses on the relation of elite $H$. Andiwarto with sub-elite and village community in maintaining Masra family dynasty for village head position. Masra family dynasty has run for a long time. For 150 years, Masra family descendants occupy the village head position. The survival of Masra family dynasty in the Gapurana Village Government is studied in the relation of $H$. Andiwarto, who is Masra descendant with subelite and village community to maintain Masra family descendant dynasty as a village head. This research used a qualitative method with descriptive research type. The elite theory proposed by Suzanne Keller was used to analyze the relation of elite, sub-elite, and the community. This theory has 4 (four) indicators: the governing elite, the ruling elite, the not ruling elite, and the community. Based on these indicators and the results of this research, the relation built by $H$. Andiwarto in maintaining Masra family dynasti consists of three relations: relation with the political elite, relation with economic elite, and relation with the social elite. The political elite's relationship is vital in maintaining the Masra family descendant dynasty. In contrast, the relation between the economic elite and the social elite supports relations for keeping the legitimacy of the village community towards Masra descendants.

Keywords: Dynasty; Elite Relation; Gapurana Village; Sub-Elite

Copyright (C) 2021. Owned by Author(s), published by Society. This is an open-access article under the CC-BY-NC-SA license. 


\section{Introduction}

Masra family is a political phenomenon in the government of Gapurana village of Talango sub-district in Sumenep regency. The family has ruled the village for approximately 150 years, five generations, making it a dynasty of Masra.

The dynasty started their reign in Gapurana in the 1850s, started by Masra, leading the village for fifty years. He was succeeded by his nephew, Singo Sasmito, who took charge for another fifty years. After his tenure ended, Singotruno, his son-in-law, was instated for the next thirty years. Then, during the New Order era, his son, H. Moh. Anwar Rosyidi, succeeded him for two periods, i.e., twenty years, followed by $\mathrm{Hj} \mathrm{Tu}$ 'inah, his daughter in law, for two periods or fifteen years. Since the regulation mentions that a person cannot hold the same position of village head for more than two periods, her husband H. Andiwarto, the son of H. Moh. Anwar Rosyidi, took charge for two periods, i.e., from 2013 to 2019 and from 2019 to 2025. Researches present the history of Gapurana village head in figure and table section.

Masra dynasty in the governance of Gapurana can be seen from two aspects: negative and positive. The negative aspect is inhibiting new elites from the community. The five-generation long Masra family dynasty has closed the opportunity of other individuals to lead the village. Although democracy developed well in Gapurana, there were times when the Masra family did not have any political opponents. The positive aspect is that the dynasty has become evidence of the Masra family's success in leading the village, which is observable from the legitimacy given by the villagers to the Masra family.

Based on the perspectives above, this research was encouraged to identify factors that make the family stay in charge. H. Andiwarto's success in keeping the dynasty in the governance is evidenced by the good governance and his closeness with the village's elites. Those are the reasons for the research to discuss the relations between the elite (H. Andiwarto), sub elites, ordinary people of Gapurana, and the family's success in its leadership in the Gapurana village of Sumenep regency in East Java.

\section{Literature Review}

\subsection{Elite and Sub-Elite}

Keller (1998) has stated that a community is divided into two classes. The first class is a smaller group of individuals who can govern. It is divided into ruling elites and non-ruling elites or sub-elite or determining elite. The second class is comprised of those who were created to be governed.

For Keller (1998), the strong position of elites in people's life is the effect of the mutual relationship between elites and sub-elites. "The role of elites as determinants" is certainly inseparable from the majority. Therefore, the functions are, first, maintaining the relationship with the community as both individuals and groups to achieve the objectives; second, uniting collectively definitive agreements; third, symbolizing associations through various ways and meetings. In this case, we can see how elites' functions are always identical with the people requiring the elites.

Regarding elite legitimacy, Weber, as cited in Haryanto (2017), mentioned three types of "Legitimate Domination" show in what condition an individual or a group can dominate many people. The legitimations are Traditional Domination, Charismatic Domination, and Legal Rational Domination. Traditional domination recognizes elites based on the tradition and values applicable in the community in question. In contrast, legal-rational domination is 
recognition to elites due to their capability and their fulfillment of regulations as stipulated by applicable rules.

\subsection{Culture of Madurese People}

Madurese's views of life with a positive social life value are always based on Islamic values. It is because most of the population is Muslims. They make courtesy their foundation in living their social life as they hold the concept of Buppa'Babu', Guruh, Ratoh until now (Taufiqurrahman, 2012).

Buppa' Babu' means father, mother, or parents (Taufiqurrahman, 2012). Madurese people believe that the first people who deserve their honor are parents raising them. The second people are Guruh, teachers. Initially, they refer to Kyai, informal religious teachers from whom Madurese received education in pesantren since most of them did not receive formal education in the past. Nowadays, formal education teachers also receive the same honor. The third people are Ratoh, king, which refers to formal leaders such as village head, regent, governor, or president.

\section{Research Methodology}

This qualitative research uses a descriptive approach. The data was obtained from interviews, observations, and photos concerning the relationship between $\mathrm{H}$. Andiwarto and the village's sub elites to preserve the Masra family dynasty in the village government.

This study was conducted in Gapurana village, Talango sub-district, Sumenep Regency, East Java Province. The primary data was harvested from in-depth interviews with people contributing to the preservation of the Masra family in the village governance, and the secondary was gathered from documents such as the village's profile, governance structure, etc.

Following primary and secondary data gathering, selection and analysis were conducted. The data was re-analyzed and arranged into a descriptive explanation about the relations between elites, sub-elites, and commoners in keeping Masra dynasty in the government. The final step in the analysis is conclusion drawing based on data and descriptive explanation made by the researchers.

Table 1. History of Gapurana Village Head

\begin{tabular}{|c|c|}
\hline Name & Term of Office \\
\hline Masra & $1^{\text {st }}$ Village Head (1850-1900) \\
\hline Singo Sasmito & $2^{\text {nd }}$ Village Head (1900-1949) \\
\hline Singutruno & 3rd Village Head (1949-1979) \\
\hline H. Moh. Anwar Rasyidi & $\begin{array}{c}4^{\text {th }} \text { Village Head } \\
\text { First Period (1979-1990) } \\
\text { Second Period (1990-1998) }\end{array}$ \\
\hline Hj. Tu'inah & $\begin{array}{c}5^{\text {th }} \text { Village Head } \\
\text { First Period (1998-2007) } \\
\text { Second Period (2007-2013) }\end{array}$ \\
\hline H. Andiwarto & $\begin{array}{c}6^{\text {th }} \text { Village Head } \\
\text { First Period (2013-2019) } \\
\text { Second Period (2019-2025) }\end{array}$ \\
\hline
\end{tabular}

Source: Data Processed (2020) 


\section{Results and Discussion}

\subsection{Elite, Sub-Elite, and People of Gapurana Village}

According to Keller (1998), the position of elite and sub-elite in maintaining the Masra dynasty in administration can be analyzed. The position of $\mathrm{H}$. Andiwarto as the elite with the highest position in the village and the party interested in maintaining the Masra dynasty has placed him as the ruling elite. Sub-elites fill the position of the non-ruling elite, i.e., elite groups with no ruling power but are influential on people's life due to their closeness with people. The sub-elites in this research are (1) political elites such as the village's apparatuses, i.e., Hj. Tu'inah and Wiwid Harjo Widanto, (2) social elites i.e. K. H. Kamaruddin, Hengky Abdurrahman, and Kutnawati, and (3) economic elite, who also a political elite, Wiwid Harjo Widanto. The secondclass group in this research is Gapurana villagers.

\subsection{Legitimations of Elite (H. Andiwarto) and Sub-Elite in Gapurana Village}

This research is essential to explain the legitimation of the Masra family and the sub-elite given by the villagers. The community's legitimation of $\mathrm{H}$. Andiwarto and the sub-elite can be analyzed using traditional and legal-rational domination. The legitimation gained by $H$. Andiwarto and the elite from the community consists of three influential factors: the genuine Madurese culture of respecting others, the Masra family's influence, and the community's legitimation to the community sub-elite. The three effects are explained in the following.

\subsubsection{The Effect of Honoring Culture of Madurese People}

Based on the explanation about the culture of the Madurese people (Taufiqurrahman, 2012) above, we can see that Gapurana villagers honor H. Andiwarto as their village head as taught by Madurese traditional culture. Furthermore, the honoring of the Madurese people to religious figures, i.e., Kyai, has strengthened the legitimation of K. H. Kamaruddin as a religious figure in the village. The legitimation of $H$. Andiwarto as the village head and K. $H$. Kamaruddin legitimation is traditional domination. According to Weber, as cited in Haryanto (2017), people in this legitimation have strong beliefs about the holiness of tradition.

\subsubsection{The Effect of Masra Family Dynasty}

The legitimation given by the community to the Masra family is also based on people's beliefs. The villagers came and asked Masra to be the head of Gapurana village. He accepted the request with the condition that his position must not be replaced until the seventh descendant (Fitriya Kabarriya, Personal Communication, February 28, 2020). Masra took an oath that his position would not be taken over until seven generations based on the agreement. The researchers have categorized people's trust in the rooting agreements concerning the Masra family dynasty as traditional domination legitimation.

\subsubsection{The Effect of Sub-Elite's Role (Sub-Elite Legitimation)}

The roles of elites in the life of villagers are legal-rational domination. In this type of legitimation, elites are legitimate due to their ability to fulfill the agreed convention by the community. Their roles in social and political life are the fulfillment of conventions applicable in the life of the village community. The legitimation of sub-elites and their relations with $\mathrm{H}$. Andiwarto have created a stronger recognition by the people to H. Andiwarto. This research will further discuss such legitimation in the next sub-chapter to avoid repetition of explanation. 


\subsection{The Relation of $\mathrm{H}$. Andiwarto as the Elite with the Sub-Elite and the Community in Preserving Masra Family Dynasty}

Relations between elites are one way to gain victory in democracy contestation. The fierce competition makes leader candidate elites build relations with other elites in the community to have a better chance of winning. As a mutual relationship between elites and sub-elite, according to Keller (1998), in this research, sub-elite are the bridge between H. Andiwarto and the villagers. It is through them that the community makes a collective agreement.

The relation between $\mathrm{H}$. Andiwarto and the sub-elites started from the fierce village head election in 2013. There was a movement to bring down the dynasty at the end of $\mathrm{Hj} \mathrm{Tu}^{\prime}$ inah's administration. Her husband went forward for candidacy, and he needed a lot of effort the keep the dynasty in charge.

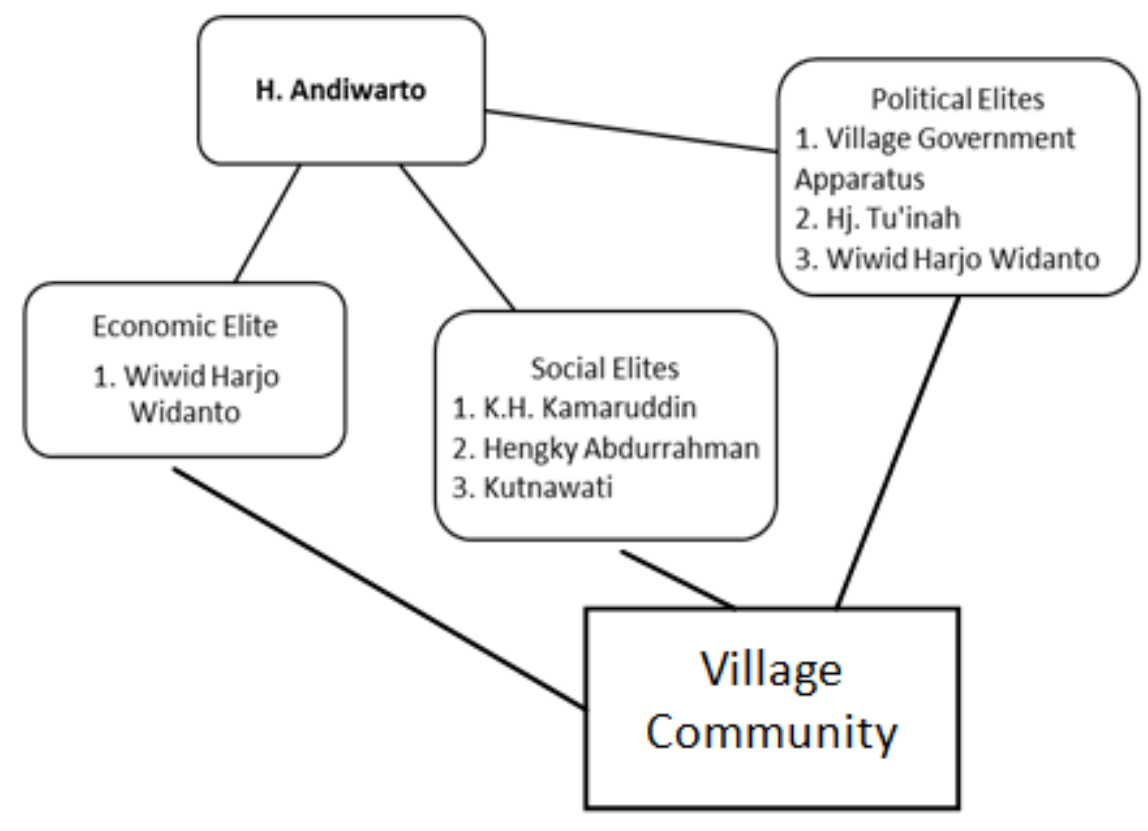

Figure 1. Andiwarto Relationship with Sub-Elite in Maintaining Masra Family Dynasty Source: Data Processed (2020)

The relationship that has been established since the 2013 election remains even after $\mathrm{H}$. Andiwarto was elected until 2019, the final year of the term. The relations built by the elite $(\mathrm{H}$. Andiwarto) with sub-elite and the villagers of Gapurana from 2013 until the election in 2019 are as follows:

\subsubsection{Relation with Political Elite}

H. Andiwarto has built relations with political elites who have stronger influences, and he has intensively interacted with the villagers, i.e., the government apparatuses of Gapurana. $\mathrm{He}$ was supported by $\mathrm{Hj} \mathrm{Tu}$ 'inah (former village head who is also his wife) and is related with Wiwid Harjo Widanto (his brother who is also a member of the House of Representatives of Sumenep regency for the term of 2009-2014 and 2019-2024).

His relation with village apparatuses was used to bring good services to the society in administration and social matters. He established a system that can provide the villagers with a quick administrative process to get letters of police record, family economic level, business permit, and resident relocation. In conformant with Keller (1998) about sub-elites, village 
apparatuses have a prominent role in the life of the villagers, and they have access to $H$. Andiwarto as the ruling elite. Hence, the village government apparatuses are in the position of sub-elite.

The service provided by the village apparatuses was considered improving the good valuation from the public concerning the village head's performance (AW, Personal Communication, February 2020), which has created legal-rational domination legitimation. The public regarded the good services as the capacity of $\mathrm{H}$. Andiwarto in leading the village. The role of the village apparatuses in keeping the dynasty in charge also ensures their positions as the village's political elites.

The relation built by $\mathrm{H}$. Andiwarto with $\mathrm{Hj} \mathrm{Tu}$ 'inah was aimed for the mutual interest of keeping the Masra family dynasty. As stated by Suzanne Keller, the elite and sub-elites are individuals who have the leverage and influence in the community's life. $\mathrm{Hj} \mathrm{Tu}^{\prime}$ inah has an influential role in women because she is active in women organizations such as Muslimat and Fatayat NU (Hj. Tu'inah, Personal Communication, February 2020). This couple is also present in public activities such as social gatherings and religious events - the history of Hj. Tu'inah's leadership as the former village head, her activeness in social events, and her relation with $\mathrm{H}$. Andiwarto have created legal-rational domination.

Finally, the relations built by $\mathrm{H}$. Andiwarto with Wiwid Harjo Widanto were based on mutual interest, that is, to win the Wiwid in the legislative member election in Sumenep regency on April 17, 2019, and to win Masra family in Gapurana village head election on November 7, 2019. As stated by Keller (1998) concerning elites and sub-elites, the researchers have categorized Wiwid as the sub-elite as he is a political elite who does not hold the position of the "ruling" elite of Gapurana.

Wiwid had the most votes in the Election Region I in Sumenep regency with 7,698 votes (The General Election Commission of Sumenep Regency, 2020). People's trust in H. Andiwarto as Gapurana village head of the 2013-2019 period has affected Wiwid's triumph in the legislative board election. Most of the votes came from Gapurana, although he was supported by Partai Keadilan Sejahtera (PKS), a party that differs in views from the publicly adhered organization Nahdlatul Ulama (NU) (H. Andiwarto, Personal Communication, February 2020).

Wiwid's role in his candidacy and gaining a legislative board member position is detrimental to the Masra family dynasty. He has built public trust so that the people voted for the family member by absorbing people's aspiration to develop the village as stated in his political promises (Wiwid Harjo Widanto, Personal Communication, February 2020). Luckily, after being elected as the board member, he was placed in Commission 3, related to the development. Therefore, the legislative board's program can propose people's road and irrigation construction aspirations. His position as a legislative board member finally brought H. Andiwarto to be reelected for the 2019-2024 term. Based on the explanation above, H. Andiwarto and Wiwid have gained legal-rational domination legitimation from the villagers.

\subsubsection{Relation with Economic Elite}

The researchers have categorized Wiwid Harjo Widanto as an economic and, at the same time, political elite. Although he was not elected as a legislative member for the 2014-2019 period, his history as a former legislative board member has led him to an economic elite. He actively participated in youth activities and religious events, such as sermons and Mawlid, as a donor (Wiwid Harjo Widanto, Personal Communication, February 2020). Hence, Wiwid has gained legal-rational domination legitimation from the villagers. His activeness in funding such

Copyright (C) 2021. Owned by Author(s), published by Society. This is an open-access article under the CC-BY-NC-SA license. 
events has created some respect for the family of $\mathrm{H}$. Andiwarto, so the community still chooses the descendant of Masra as their village head. It also serves as social capital to win the election as a legislative board member for 2019-2024.

\subsubsection{Relation with Social Elite}

H. Andiwarto also built relations with social elites such as K. H. Kamaruddin (a Kyai), Hengky Abdurrahman (a youth figure), and Kutnawati (a woman figure). According to their field of expertise, all three have an important role in the community's life.

\section{1) Relation with K. H. Kamaruddin}

Madurese people tend to be monolithic in religion, and most of them are students of pesantren who adhere to religious values. The condition requires H. Andiwarto to have good relationships with religious figures to maintain legitimation from the villagers.

K. H. Kamaruddin is the head of Nurul Jannah mosque administration in Gapurana. As explained by Keller (1998) about sub-elites, the position and role of Kyai in Madurese people have placed the religious figure into a sub-elite group. In the previous sub-chapter, the researchers have explained the traditional domination legitimation attached to Kyai. K. $H$. Kamaruddin, in preserving the Masra family dynasty, is making approaches to the villagers during certain events such as religious sermons.

H. Andiwarto was also involved in religious education. He officially allocated money through the village budget to pay Quran recitation teachers and organize religious events every year. The Gapurana village has allocated IDR 17.200.000 to pay 42 Quran recitation teachers in 2019 (Pemerintah Desa Gapurana, 2019). Concerning public development concerning culture and religion, a special allocation of IDR 2.426.483 was made for Mawlid events.

In addition, H. Andiwarto has his Friday prayers in different mosques every week to interact with a wider community (K.H. Kamaruddin, Personal Communication, February 2020). The role of $\mathrm{H}$. Andiwarto in religious education has created legal-rational domination legitimation for the sustainability of the Masra family dynasty.

\section{2) Relation with Hengky Abdurrahman}

Confirming the idea of Keller (1998), individuals with special roles and influences, in this case, Hengky Abdurrahman, are sub-elite (the determining elites). Hengky is an active youngster in Karang Taruna, a village youth organization, and other organizations outside the village government. His strategic position has linked $H$. Andiwarto and the village's youngsters.

H. Andiwarto donated his private money to make costumes for the youths, finance parade contests, and other Independence Day celebrations (H. Andiwarto, Personal Communication, February 2020). He also attended youth events in the village (Hengky Abdurahman, Personal Communication, February 2020). What he has done has created bondage between him and the youngsters. The role of youth figures in keeping the Masra family dynasty is directly inviting youths to remember what $\mathrm{H}$. Andiwarto has given. From the explanation above, we can conclude that $\mathrm{H}$. Andiwarto has gained legal-rational domination legitimation from the youngsters.

\section{3) Relation with Kutnawati}

The relation with woman figures continues the relation that $\mathrm{Hj}$ has built. $\mathrm{Tu}^{\prime}$ inah during her term as the head of Gapurana village. In line with Keller (1998), the strategic position and role 
of Kutnawati in the life of the villagers have directly placed her as one of the sub-elites. Her role is relatively universal in women, religious organizations, and even social organizations. Her position can be said as the accomplice of $\mathrm{Hj}$. Tu'inah.

Kutnawati is actively involved in Posyandu (children and maternal care service), Fatayat, and Muslimat NU (Kutnawati, Personal Communication, February 2020). She plays an important role in maintaining women's trust in Fatayat and Muslimat NU toward the Masra family through the activities. In addition, she also reminded her relatives to elect the descendants of Masra, as willed by her great grandparents. The legitimation gained by $\mathrm{H}$. Andiwarto from the loyalty and role of Kutnawati in sustaining the Masra family dynasty is traditional domination, in which Kutnawati preserves the tradition based on the will of her ancestors.

Based on the explanation above, relations with political elites are pivotal in the Masra family dynasty's sustenance. The village apparatuses, Wiwid Harjo and $\mathrm{Hj} \mathrm{Tu}$ 'inah, are directed to absorb the villagers' aspirations and serve them. Other relations, such as the relation with religious figures and youth and woman figures, support the Masra family dynasty's sustainability.

\section{Conclusion}

The relations used by $\mathrm{H}$. Andiwarto in preserving the Masra family dynasty in the Gapurana village government are related to political elites, economic elites, and social elites. The relation of the elite $(\mathrm{H}$. Andiwarto) with the political elites is vital in determining the sustainability of the Masra family dynasty. In contrast, the relation with social elites is a supporting determinant.

\section{Acknowledgment}

The authors are grateful to express gratitude to those who have had the pleasure of cooperating during this research.

\section{Declaration of Conflicting Interests}

The authors have declared no potential conflicts of interest concerning the study, authorship, and/or publication of this article,

\section{References}

Abdurahman, H. (2020, February). Personal Communication [Personal Interview].

Andiwarto, H. (2020, February). Personal Communication [Personal Interview].

AW. (2020, February). Personal Communication [Personal Interview].

Haryanto. (2017). Elit, Massa, dan Kekuasaan: Suatu Bahasan Pengantar. Yogyakarta, Indonesia:

Research Center for Politics and Government (PolGov).

Kabarriya, F. (2020, February 28). Personal Communication [Personal Interview].

Kamaruddin, K. H. (2020, February). Personal Communication [Personal Interview].

Keller. S. (1998). Penguasa dan Kelompok Elite, Peran Elite Penentu dalam Masyarakat Modern. Jakarta, Indonesia: CV Rajawali.

Kutnawati. (2020, February). Personal Communication [Personal Interview].

Pemerintah Desa Gapurana. (2019). Laporan Realisasi Pelaksanaan Anggaran Pendapatan dan Belanja Desa Tahun 2019. Gapurana, Indonesia: Author. 
The Relation of Elite, Sub-Elite, and Village Community in Maintaining the Masra Family Dynasty in Gapurana Village, Sumenep Regency: Study on the H. Andiwarto Regime in 2013-2019

Taufiqurrahman, T. (2012). Identitas Budaya Madura. Karsa: Jurnal Sosial Dan Budaya Keislaman, 11(1), $1-11$. Retrieved from

http:/ / ejournal.iainmadura.ac.id/index.php/karsa/article/view/143

Tu'inah, Hj. (2020, February). Personal Communication [Personal Interview].

Widanto, W. H. (2020, February). Personal Communication [Personal Interview].

\section{About the Authors}

1. Ruth Agnesia Sembiring obtained her Master's degree from Universitas Gadjah Mada, Indonesia, in 2014. The author is an Assistant Professor at the Department of Government Science, Faculty of Administrative Science, Universitas Brawijaya, Indonesia.

E-Mail: nesi.biring@gmail.com

2. Mishbahul Khoiri obtained his Bachelor's degree in Government Science from Universitas Brawijaya, Indonesia, in 2020. The author is currently a student at the Postgraduate Program in Public Administration, Faculty of Administrative Science, Universitas Brawijaya, Indonesia. 